\title{
The Civil Legal Protection of One's Image Right: A Comparative Study between Jordan, France, and Egypt
}

\author{
Dr. Murad Mahmoud Shnikat \\ Department of Law/ Al-Balqa Applied University
}

\begin{abstract}
Laws are still incapable to protect personality rights. They are also incapable to provide an effective legal framework for protecting such rights. The same applies to one's rights to privacy, especially image right. Protecting the latter right is necessary due to the recent technological development in the field of photography. Protecting one's image right is also necessary due to the availability of various means that can be used for infringing this right. Having such a variety led to the rise of legal problems and issues. Hence, the present study aimed to explore the civil legal protection of one's image right under the Jordanian, French, and Egyptian laws. It was found that one's image right is protected by the general provision set in article 48 of the Jordanian civil law. The latter article deals with personality rights in general. However, the Jordanian legislator must adopt the same approach adopted by the French legislator. That is represented in adjusting article 48 of the Jordanian civil law to protect the image right as an independent right. That must be done due to the significance of the latter right.
\end{abstract}

Keywords: Image right, personality rights, privacy rights.

DOI: $10.7176 / J L P G / 82-17$

\section{Introduction:}

Before the invention of the modern photographic devices, people didn't suffer from any legal problem related to photography. During that time, images were created through drawing them by hand, whether it is done by a pencil or a brush. This method requires sitting still in front of the drawer at a specific place and in a specific pose till the drawer finishes the painting. Hence, this method of creating images can't be carried out without one's knowledge and prior approval. However, during the recent years, the world has witnessed scientific and technological developments, especially in the field of photography and photographic devices. In addition, digital cameras were invented and satellite channels have been increasing. These changes represent a threat to one's personal life, and privacy against. That is because such means can be used by obtrusive people to infringe others' right to privacy.

The theory of rights has developed much and people have become more aware about the significance of having their personality rights protected. That has led many jurists and judicial bodies to interfere and recognize several new rights. Such rights include one's right to protect his image. Similar to other rights, one is entitled to take actions to protect the aforementioned right from any infringement. At the beginning of the second half of the $19^{\text {th }}$ century, the French judiciary and jurists have recognized one's right to protect his image. The latter right authorizes one to object to publishing or creating his image without having his prior approval. Recognizing this right is a way for showing respect and appreciation to human beings and society. It also serves as an indicator that the society is developed.

In some countries, the judiciary is the only authority responsible for addressing the issues related to one's right to protect his image. In other countries, legislators have interfered through recognizing the latter right. This recognition is represented in enacting clear legislations. Such legislations may be represented in the form of legislations that protect this right in specific or legislations that include general rules for protecting the personality rights in general. The latter legislations include article 48 of the Jordanian civil law which holds No. 43 of 1976 and article 50 of the Egyptian civil law which holds No. 131 of 1948. As for the legislations that protect the image right in specific, they may be penal or civil legislations. That includes the legislations including the traditional protection rules (civil liability rules) which are included in the French civil law. 


\section{The Study's Significance:}

There must be an effective civil legal protection for one's right to protect his image. Such a protection must be enforced by providing all the necessary legal means for fighting against the infringement committed through the photographic devices. This protection is needed because such devices have been widely spreading among individuals and journalists.

It is important to recognize personality rights such as: image right. However, it is more important to have public institutions respecting the law and abiding it. Such institutions must also respect the rights protected by the law.

Laws are still incapable to protect personality rights. They are also incapable to provide an effective legal framework for protecting such rights. The same applies to one's rights to privacy, especially to image right. Protecting the latter right is necessary due to the recent technological development in the field of photography. Protecting one's image right is also necessary due to the availability of various means that can be used for infringing this right. Having such a variety led to the rise of legal problems and issues. Thus, there must be specialized studies for examining these problems and issues.

\section{Statement of the Problem:}

The problem of the present study is represented in seeking to explore the civil legal protection of one's image right. That was explored through exploring the legal framework set for protecting the latter right. Such protection was explored through identifying the mechanism used for determining the value of the compensation set for making up for the damages resulting from infringing someone's image right. All of these thigs were explored to identify whether the existing legislations of the Jordanian civil law are sufficient for ensuring that the image right. In case they aren't sufficient, that means that there is a need to enforce new legislations.

\section{The Study's Methodology:}

The researcher of the present study adopted a descriptive approach. That was done through examining the relevant articles of the Jordanian civil law. An analytical approach was also adopted through analyzing these articles and drawing out the relevant provisions. A comparative approach was also adopted through comparing the Jordanian law with other laws.

\section{The Study's Parts:}

The present study is divided into two main parts. These sections are mentioned below: Part (1): The legal framework set for protecting one's image right

Part (2): The compensation for the damages resulting from violating someone's image right

Part (1): The legal framework set for protecting one's image right

In order to identify the legal framework set for protecting one's image right, the meaning of this right must be identified. In addition, its legal nature, and essence must be identified. In addition, the forms of violating it shall be identified too. These things shall be identified in the following sections:

\section{The meaning of image right}

In order to identify the meaning of this expression, the researcher shall present its definition and characteristics. The researcher also aimed to identify the relationship between image right and privacy rights. These things shall be identified through the following three sub-sections: 


\section{The definition of image right:}

In general, image is defined as a visual representation of the body of something or someone. It is represented through projecting it on wood, paper or etc... That can be done through using various means, such as: drawing, carving, photographic devices, or etc.... ${ }^{1}$

As for the image right, it is defined as one's right to object to the creation or publication of his image without having his prior approval. That applies whether the image is created through drawing it on paper, glass, or fabric, or through using the modern technological devices, such as the photographic devices ${ }^{2}$. The image right can be also defined as (one's right to prevent others from drawing him or taking his photos without having his prior approval. This right also involves preventing others from publishing his photo through written or visual media $)^{3}$.

Based on the aforementioned definitions, it can be concluded that image right is not restricted only to one's right to object to the publication of his image without having his prior approval. In fact, this right also involves one's right to object to taking his photo without having his prior approval. Those definitions refute the claims that image right is restricted only to one's right to object to the publication of his image without having his prior approval.

The judgments of several judges in the French judiciary indicate that image right is not restricted only to one's right to object to the publication of his image without having his prior approval. Based on the latter judgments, the image right also involves one's right to object to taking his photo without having his prior approval ${ }^{4}$. Some jurists believe that image right is defined as (the right that entitles the one appearing in the photo to object to the creation of his image in any manner or publishing it without having his prior approval $)^{5}$.

\section{Characteristics of the image right}

This right is a personality right which is characterized with several characteristics. These characteristics distinguish this right from other rights. Some of these characteristics are presented below:

\section{Image right is a public absolute right:}

This right is one of the public rights. That means that it is a right enjoyed by all people because they are humans. That applies regardless of one's nationality, religion, gender and color. In other words, the only condition that must be fulfilled to enjoy public rights is represented in being a human being. To be specific, this right is a fixed right enjoyed by any natural person since his birth till his death.

One's image is an extension and reflection of one's personality. Thus, the image right is a personality right ${ }^{6}$. In addition, the image right is an absolute right. That means that the one appearing in the image has the right to defend his right and hold on to it in under all conditions in case it was violated. That means that there is a negative public

\footnotetext{
${ }^{1}$ Bairk Fares Al-Jboury. Personality rights and its civil protection: A comparative study: Al-Kotob Al-Qanuniah distribution and publishing house. Cairo. 2009. p. 108

${ }^{2}$ Dr. Mamdouh Mohammad Khairy Al-Maslamy. The civil liability arising from violating one's right to protect his image in the light of the development of the modern communication means. Al-Nahda Al-Arabeya publishing and distribution house. Cairo. 2001. p. 12

${ }^{3}$ Dr. Saeed Jaber. Image protection right. Al-Nahda Al-Arabeya distribution and publishing house. Cairo. 1986. p. 14

${ }^{4}$ Dr. Hisham Mohammad Farid. The penal protection for one's right to protect his image. Al-Alat Al-Haditha distribution and publishing house. Asyoot. (Year of publication is not available). p. 23

${ }^{5}$ Kayser Pile droit a 1,image,Mé langes Roubier,t.II,Dalloz et Sirey,1961,pp467-468

${ }^{6}$ Dr. Husam Al-Deen Kamel Al-Ahwani. One's right to show respect for his private life (Privacy right): A comparative study. Al-Nahda Al-Arabeya publishing and distribution house. Cairo. 1978. p. 160
} 
duty enforced on all people in this regard. This duty is represented in respecting others' image right and refraining from infringing it $^{1}$.

\section{Image right is not a financial right.}

This right is considered one of the personality rights. It is also considered as a moral right that is attached to each one's personality. One can't be deprived from this right. One is provided with this right to protect his moral being. Thus, this right is considered a non-financial right which value can't be assessed by money. In other words, no price can be set for estimating the value of this right ${ }^{2}$.

It should be noted that each one has the right to use his image for commercial purposes. This right is a personality right. In the United States, it is called the right of publicity. Exploiting someone's image for commercial purposes without his approval shall be considered damaging to that person. The latter person has an exclusive right that entitles him to control the way his image and facial features are utilized in his profession. That applies whether this person is from the public or a celebrity, such as: an athlete, actor, or model. However, such a right is considered violated only in case people could recognize the one appearing in the photo that got published without the prior approval ${ }^{3}$. In such a violation, this right enjoys a specific financial value. Thus, the one who violates this right must pay a compensation to make up for the damages resulting from the act ${ }^{4}$.

It should be noted that this issue was tackled by the French civil law. Under the latter law, if someone's image is published without his prior approval, he shall be entitled to claim for stopping this violation and getting a compensation for the moral damages. Such damages are represented in the bodily and psychological damages which resulted from publishing his photo without his prior approval. That represents an infringement of his image right $^{5}$. The same is adopted by article 48 of the Jordanian civil law.

\section{The image right can't be disposed}

Image right is a non-financial personality right. Thus, one can't dispose this right willingly. In other words, this right can't be disposed under any financial transaction. That means that one can't dispose it for money or for free. In addition, the financial compensation obtained for the violation of this right can't be seized ${ }^{6}$. In addition, creditors can't claim for getting this financial compensation if it's not given yet by the infringer. That is because such a claim violates the nature of personality rights. In other words, the compensation obtained for violating the image right can't serve as a guarantee for paying back a debt ${ }^{7}$. That is confirmed by article $366 / 1$ of the Jordanian civil law. That latter law states that each creditor is entitled to exercise all his rights of the debtor in the name of that debtor even if the debt is not due yet. Exceptions to that include the debtor's personality rights and the things that can't be seized ${ }^{8}$.

\footnotetext{
${ }^{1}$ Dr. Hisham Farid. ibid. p. 23

${ }^{2}$ Dr. Mustafa Ahmad Hijazi. The journalist's civil liability for violating someone's personal life. Al-Nahd Al-Arabeya publishing and distribution house. 2004. 132

${ }^{3}$ Pascale B. \& sAmaud C: AHRC,PPP research stream - France:Id,2000, p146

${ }^{4}$ Dr. Mohammad Wasel. Personality rights: A comparative study. (There is no publication house). Damascus University. 1995. p. 77

${ }^{5}$ Dr. Abed Al-Hadi Fawzi Al-Awadi. The general theory of rights. . Al-Nahda Al-Arabeya publishing and distribution house. Cairo. 2006. p. 34

${ }^{6}$ Dr. Hasan Keerah. An introduction to law, specifically the Lebanese and Egyptian laws. The second section: the general theory of rights. Makawi Library. Beirut. 1977. p. 574.

${ }^{7}$ Mohammad Wasel. ibid. p. 77

${ }^{8}$ The same is adopted by article (235/1) of the Egyptian civil right
} 
Image right is related to the public order because it is a personal freedom. Article 47 of the Jordanian civil law governs this right. The latter article states that no has the right to waive his / her personal freedom ${ }^{1}$

One's right to protect his image can't be disposed. That means that this right can't be sold, given, inherited ${ }^{2}$. In addition, no one has the right to capture someone's photo or publish it without having a prior approval from the one appearing in the photo. However, giving this approval doesn't mean that the latter person is disposing his right which represents a violation of the law. In fact, giving this approval means that the person is waiving his right temporary and under specific conditions. Such an approval is given for obtaining a specific benefit ${ }^{3}$

\section{The statute of limitations is not applicable to the acquisition nor deprivation of image right}

Under the statute of limitations, if the plaintiff doesn't file a lawsuit within a specific duration, he shall not have the right to file a lawsuit after this duration. In case he filed a lawsuit after this duration, the lawsuit shall be dismissed. This duration is determined by the law. This right can't be acquired or taken from the one entitled to exercise it under the statute of limitations. That applies regardless of the duration that has passed without exercising this right ${ }^{4}$. Jurists support that due to the non-financial nature of the latter right. They support that because the latter law can't be disposed nor exchanged through any financial transaction. In other words, it is not something that can be given to others ${ }^{5}$. Under the rules of the law, the things that can't be disposed can't be subjected to the statute of limitations ${ }^{6}$.

Similar to other personality rights, the statute of limitations is not applicable to the acquisition nor deprivation of the image right. That is considered one of the characteristics of the latter right. Despite that, the liability lawsuits filed for infringing this right shall be dismissed in case the limitation period specified in the law passed. That shall be discussed further in other sections.

\section{The relationship between image right and privacy rights}

There is a debate among jurists about the answer to the following question: (Is image right considered one of the privacy rights?). Jurists' answers to this question are three. These are answers are listed below:

\section{Image right is one of the personal life rights}

Some jurists believe that image right is one of one's rights to show respect for his personal life ${ }^{7}$. Those jurists also believe that image right is protected by the law because it's a personality right. They also believe that violating the image right is a violation for one's right to show respect for his personal life ${ }^{8}$. Thus, protecting people from capturing their photos against their will lies within the scope of their personal life rights. To be more specific, one's rights to respect his personal life involves one's right to protect his image'. Violating one's image right is considered as an infringement of someone's moral being, especially if the image is degrading or mocking the one appearing in it $^{10}$.

\footnotetext{
${ }^{1}$ The same is adopted by article (49) of the Egyptian civil right

${ }^{2}$ Dr. Mamdouh Khalil Al-Bahar. The protection of personal life in the penal law. A comparative study. Dar Al-Thaqafeh Library. Amman 1996. p. 289

${ }^{3}$ Dr. Saeed Jaber. ibid. p. 131

${ }^{4}$ Dr. Abed Al-Hadi Fawzi Al-Awadi. ibid. p. 55

${ }^{5}$ Dr. Mohammad Wasel. ibid. p. 79

${ }^{6}$ Bairk Fares Al-Jboury. ibid. p. 33

${ }^{7}$ Dr. Mustafa Ahmad Hijazi. ibid. p. 88

${ }^{8}$ Dr. Mahmoud Abed Al-Rahman Mohammad. The scope personal life right. Al-Nahda Al-Arabeya publishing and distribution house. Cairo. (Year of publication is not available). p. 231

${ }^{9}$ Dr. Hisham Mohammad Farid. ibid. p. 37

${ }^{10}$ Lindon (R): Observation sous trib.gr.inst,Paris,11 juillet 1973, p421
} 
Some jurists have supported this line of thought (i.e. the belief that image right is one of one's rights to show respect for his personal life $)^{1}$. Those jurists define personal life as a group of personal choices which must be respected because it's one's right to respect his personal life. Those jurists state that any infringement of someone's image right represents a violation for his privacy rights.

This line of thought is inconsistent with the second line of thought. The jurists who adopt the second line of thought believe that one's image right is an independent right that is distinguished from privacy rights.

\section{The image right is an independent right, rather than being one of the privacy rights:}

The jurists who adopt the second line of thought ${ }^{2}$ believe that one's image right is an independent right that is distinguished from privacy rights. They also believe that the image right is not one of the privacy rights. That is because the laws that protect this right is different from the laws that protect privacy rights. They believe so because personal life is restricted to the aspects of one's life while he's at private places. Those jurists believe that the ones violating the image right shall be held liable. That applies even if the photo doesn't reveal aspects from one's personal life.

Under this line of thought, the ones who publish someone's photo during moments from his personal life, or at public places, they shall be held liable. In case the violation against someone's image right was associated with a violation against his privacy right, these rights shouldn't be confused with each other. It should be noted that each one is entitled to object to publishing his photo even if it doesn't represent an infringement of his personal life rights $^{3}$. In other words, one's image right can be violated even if the photo is captured while he's at public places. That latter violation could occur without violating one's privacy rights ${ }^{4}$.

\section{The image right may be an independent right or one of one's rights to show respect for his personal life}

According to this line of thought, one's image right has a dual nature. For instance, this right may be one of one's rights to show respect for his personal life. That applies in case the photo was captured without having his prior approval and reveals an aspect of his personal life or romantic life.

However, in case the photo was taken without a prior approval and doesn't reveal aspects of one's personal life or romantic life, then capturing and publishing it without his prior approval represent infringements of his image right only. In the latter case, the image right is an independent right and distinguished from privacy rights. Providing one with such a right aims to protect him from denigration ${ }^{5}$.

In the light of the aforementioned three lines of thought, there is a debate among jurists about whether the image right is a privacy right or an independent right. However, the researcher of the present study believes that image right is one of the personality rights (under the Egyptian and Jordanian civil laws). That applies whether this right is considered as a privacy right or an independent right. However, the researcher tends to adopt the third line of thought. In other words, the researcher believes that image right has a dual nature (i.e. it may be an independent right or one of one's rights to show respect for his personal life).

\footnotetext{
${ }^{1}$ Dr. I'smat Ahmad Al-Bahji. Protecting one's right to show respect for his personal life under human rights and civil liability. Al-Jame'a Al-Jadida publishing and distribution house. Alexandria. 2005. p. 125 - Dr. Mamdouh Khalil Al-Bahar. ibid. p. 237 ${ }^{2}$ Dr. Saeed Jaber. ibid. p. 117

${ }^{3}$ Dr. Mustafa Ahmad Hijazi. ibid. p. 88

${ }^{4}$ Dr. Husam Al-Deen Al-Ahwani. ibid. p. 77

${ }^{5}$ Dr. Mohammad Wasel. ibid. p. 344
} 


\section{The legal nature of the image right.}

There's a debate among jurists about the types and legal nature of image right and the category it belongs to. The views of those jurists shall be listed below:

\section{The image right is a property right}

During the first couple of years following the recognition of this right, the image right was perceived as being one of the property rights. That is based on the rule that one's image is a property owned by the one appearing in the image $^{1}$. According to article $1018^{2}$ of the Jordanian civil law, the owner of a property has an exclusive right to benefit from that property and dispose it through any kind of legal transaction. To be specific, the owner of a property has an exclusive right to dispose, use, and exploit that property

Under this line of thought, the natural person owns his body. The image is a representation and reflection of one's body. It is considered as an integral part of one's body and extension to one's body ${ }^{3}$. Thus, one's image is treated in a similar manner to the way any body part - such as: bones, skin, muscles, or etc....- is treated ${ }^{4}$. Each one has a distinguished image that differs from others' images. Hence, one is considered the owner of his image, photo, and facial features ${ }^{5}$.

Under this line of thought, one is fully entitled to dispose his image. To be specific, one has an exclusive right to dispose, use, and exploit his image as being the owner of his image. Under this line of thought, one is entitled to file a replevin lawsuit and claim for stopping the acts that violate his image right due to being a property right ${ }^{6}$.

Under this line of thought, the one appearing in the image (i.e. the owner) is entitled to stop any act of infringement of his property (image) right. In other words, he is entitled to prevent taking and publishing photos for him, and presenting them before others. That applies even if there is no harm associated with that ${ }^{7}$. That applies without having to prove the occurrence of any moral or financial damage resulting from the infringement act. That applies even if the defendant (photographer) didn't commit a mistake. This rule is for the favor of the plaintiff ${ }^{8}$.

Several aspects of this line of thought were criticized. Such criticism is discussed below:

First: Adopting this line of thought shall lead to mixing up between the individual entitled to claim for his image right and this right's essence

According to rules, there's a difference between property right and image right in terms of nature and characteristics. Property right is a rem right that entitles one to use, exploit and dispose his right. That requires distinguishing between the individual entitled to claim for his image right and this right's essence.

It should be noted that adopting this line of thought is inconsistent with the nature of one's image right. That is because one's facial features are considered as an integral part of one's moral being 9 . In addition, it is not logical

\footnotetext{
${ }^{1}$ Dr. Hisham Mohammad Farid. ibid. p. 31

${ }^{2}$ The same is adopted by article 544 of the French civil law of 1970 and article 802 of the Egyptian civil law

${ }^{3}$ Ravanas, J.: La protection des personnes contre la realization et la publication de leur image, Préface e Pierre Kayser, Paris, 1978, pp418-419

${ }^{4}$ Dr. Husam Al-Deen Kamel Al-Ahwani. ibid. p. 141

${ }^{5}$ Dr. Hisham Mohammad Farid. ibid. p. 33

${ }^{6}$ Dr. Mamdouh Mohammad Khairy Al-Maslamy. ibid. p. 14

${ }^{7}$ Dr. Hisham Mohammad Farid. ibid. p. 34

${ }^{8}$ Dr. Husam Al-Deen Kamel Al-Ahwani. ibid. p. 141

${ }^{9}$ Dr. Saeed Jaber. ibid. p. 109
} 
to say that one's body is the property of one's self. That is because one's body - in such a case - shall be treated as goods that one owns. By adopting this line of thought, then it can be said that his features were stolen, in case his photo was taken without his knowledge ${ }^{1}$.

Second: Image right entitles the one appearing in the image to object to the creation and publication of his image without his prior approval. In such a case, the law is not protecting something tangible. In fact, the law is protecting that aspects of one's personality. That means that such a right is a personality right, rather than being a property right $^{2}$.

\section{The image right is one of the copyrights (a moral right):}

This line of thought suggests that there are two types of rights; moral and financial rights. This line suggests that the moral rights involve image and privacy rights. This line also suggests that moral rights involve all the other personality rights which are governed by laws different than the laws governing the financial rights ${ }^{3}$. Ritchel is considered one of the most prominent figures who adopts this line of thought. The latter researcher states that one has rights over his facial features similar to the rights he has over a painting he drew or a statue he sculpted. Based on the aforementioned, one has copyrights over his face and facial features. That is because image right is similar to copyrights (which are associated with literary rights). The latter right include the author's right to publish and adjust his work and put his name on the work. The author's rights also include financial rights, such as: the exclusive right to profit from the work ${ }^{4}$.

Several aspects of this line of thought were criticized. Such criticism is discussed below:

First: This line of thought doesn't take into consideration the substantial difference between the image right and the copyright protecting the author's intellectual works.

One's facial features are an integral part of his body, rather than being one of his intellectual works. For instance, one can't design his facial features ${ }^{5}$ ! It wouldn't be logical to claim that the beautiful women who uses makeup to hide facial defaults has copyright over her face after using makeup to get a new look $^{6}$.

Second: Some of the aspects of literary rights aren't applicable to the image right

When applying the rules of the copyright laws, the photographer has moral and financial copyrights over the photo he took. That is because his copyrights can be disposed through various types of contracts and transactions. The protection given to the photographer under the law is temporary and for a specific duration. After this duration passes, this right shall pass to the public. However, the image right is a right that can't be disposed nor waived. In addition, one has an exclusive right over his image right permanently and one shall can't be deprived from this image right as long as he's living. In addition, one can't be deprived of his image right regardless of the duration that passes without exercising this right ${ }^{7}$. In the light of this criticism, the researcher believes that one's image right can't be considered similar to author's rights.

\footnotetext{
${ }^{1}$ Dr. Husam Al-Deen Kamel Al-Ahwani. ibid. p. 141

${ }^{2}$ Dr. Saeed Jaber. ibid. p. 109

${ }^{3}$ Dr. Hisham Mohammad Farid. ibid. p. 35 - Mamdouh Mohammad Khairy Al-Maslamy. ibid. p. 15

${ }^{4}$ Dr. Saeed Jaber. ibid. p. 109

${ }^{5}$ Dr. Mamdouh Khalil Al-Bahar. ibid. p. 137

${ }^{6}$ Dr. Mamdouh Mohammad Khairy Al-Maslamy. ibid. p. 16

${ }^{7}$ Hisham Mohammad Farid. ibid. p. 38
} 
There is a third line of thought that has emerged. The latter line suggests that the image right is one of the personality rights. This line became prominent and was adopted and supported by many jurists. It has more strengths than the other lines of thought.

\section{The image right is one of the personality rights.}

Many jurists criticized the aforementioned lines of thought that seek identifying the category that the image right falls under. Therefore, this line of thought emerged ${ }^{1}$. It suggests that the image right is one of the personality rights. That means that everyone enjoys this right since birth due to being a natural person. This right is an exclusive right that one acquires since his birth and can't be passed to others.

Most jurists and legislators support this line of thought ${ }^{2}$. The first one who introduced the expression personality right is a jurist called Perreau. He is the first one who discussed the way personality rights are represented in the French civil law. That was done in 1909 through an article he published in a journal called (The civil law). In this article, Perreau states that publishing things related to one's personal life without having a prior explicit or implicit approval is considered as a legal violation against one's right to show respect for his personal life. It is considered as a moral infringement of one's moral rights ${ }^{3}$.

Jurists proposed several classifications and terms to identify the meaning of personality rights. For instance, a jurist called Mazo classifies personality rights into three types; the right to work, the right to bodily integrity, and right to moral integrity. Mazo states that one's right to prevent publishing his image falls under his moral integrity right ${ }^{4}$. Some of the jurists state that image right falls under one's rights to distinguish himself from others. The latter rights include one's rights to privacy, name and nickname ${ }^{5}$.

Based on the aforementioned and regardless of the various classifications of personality rights, these rights are categorized into two main types of rights. The first type is the rights related to one's physical being, such as: the rights related to one's body. The second type is the rights related to one's moral being, such as: the rights related to one's emotions, reputation, dignity, and ideas. The rights related to one's physical being include one's right to bodily integrity. As for the rights related to one's moral being, they include image right. The latter right is represented in one's right to prevent the creation, publication, and presentation of his photos without having his prior approval. There are exceptions to that, such as: the celebrities' photos or the photos related to public events

\section{The essence of image right and forms of violating it}

Based on the aforementioned, it can be concluded that one's image right entitles one to object to the creation or publication of his image without having his implicit or explicit prior approval. That applies regardless of the way of publishing the image.

Through this section, the researcher shall discuss the issue of capturing one's photo without having his prior approval. The researcher shall also discuss the issue of denigration and exploitation of someone's character through publishing his photo. These are discussed below:

\footnotetext{
${ }^{1}$ Dr. Mamdouh Mohammad Khairy Al-Maslamy - ibid. p. 12 / Mohammad Wasel. ibid. p. 66

${ }^{2}$ Dr. Hasan Keerah. ibid. p. 570 - 571

${ }^{3}$ Mohammad Wasel. ibid. p. 83

${ }^{4}$ Dr. Abed Al-Hadi Fawzi Al-Awadi. ibid. p. 36

${ }^{5}$ Dr. Hasan Keerah. ibid. p. 572
} 


\section{capturing someone's photo without having his prior approval:}

One is entitled to object to publishing his image. Hence, his prior approval must be obtained before publishing his image. That's why he is entitled to object to taking and publishing his photo without his approval. Allowing that wouldn't be logical. That is because it wouldn't be logical to make one hope that his photo shall not be used improperly used or exploited by the one who took it! Let's assume that it's legal for the photographer to keep the photo he has taken without getting a prior approval. That would be damaging to that the reputation and honor of the one appearing on the image, especially if that person is a women. The same applies even if the photographer didn't publish the photo ${ }^{1}$.

The French judiciary recognized one's right to object to taking his photos long time ago. That can be noticed through the recent judgments issued by the French judiciary. Such judgments include the one issued by the French court of cassation on 20, October, 1998. The latter judgment was issued in the case of publishing two photos for the late president (Francois Mitterrand) while he was on his deathbed. The members of latter court stated that (taking photos of a living or dead person is something legally prohibited in case it was done without taking the approval of the one entitled to give it) ${ }^{2}$.

The photographers who take people's photos without a prior approval usually do that for publishing them later. However, sometimes photographers take people's photos for selling them to the ones appearing in the photos, rather than for publishing them. That is represented in the street photographers who take people's photos in public places. Street photographers take photos through the usual camera with taking the prior approval of the one appearing in the image. In case the approval wasn't taken, it shall be considered as an infringement of image right. That shall entitle one to object to taking his photos and claim for legal protection. The same applies to the process of drawing someone's photo. In other words, there isn't any difference between creating someone's image through traditional means, such as: drawings and taking someone's photo through the modern technological methods, such as: photographic devices, cinematographic devices, or other devices ${ }^{3}$.

The same is adopted by article 309 of the Egyptian civil law. Under the latter article, a punishment shall be enforced on the ones who capture someone's photo in a private place or transmit it through any device without a prior approval. As for article 226 / 1 of the French civil law, it states that it's an offence to infringe one's privacy right through taking, recording or transmitting his/ her photo in a private place without his / her consent. That applies regardless of the mean used for doing that.

There is a debate about the extent of penal protection of one's image right by the French and Egyptian legislators from one hand and the counterpart protection set by the Jordanian legislator. The Jordanian legislator provided such protection to this right through article 348 of the Jordanian penal law. Under the latter article, a punishment shall be enforced on the ones who infringe others' privacy right through eavesdropping, peeking or etc.... That includes making records, taking photos, and using a telescope.

It can be noticed that the Jordanian legislator did a good job by refusing to set the requirements that the Egyptian and French legislators have set for punishment. For instance, the Jordanian legislator - through article 348 of the Jordanian penal code - doesn't require having the image captured or transmitted to others in a private place. In addition, the latter legislator doesn't require having the image captured or transmitted to others through a device. That contrasts the Egyptian legislator in article 309 of the Egyptian penal code. To be specific, the Jordanian legislator considers the offense has occurred whenever the image is captured or transmitted regardless of the mean used for doing that. That means that the Jordanian legislator takes into consideration the technological advancements in the field of photography which have enabled one to take a photo using a remote device.

\footnotetext{
${ }^{1}$ Kendah Al-Shamat. One's right to have a personal life. PhD dissertation. Faculty of law. Damascus University. 2005. p. 177.

${ }^{2}$ Kendah Al-Shamat. ibid. p. 178.

${ }^{3}$ Husam Al-Deen Al-Ahwani. ibid. p. 107
} 


\section{Denigrating and exploiting someone's character through publishing his photo}

A person may agree to have his photo taken. However, that doesn't necessarily mean that he agreed to publish it. Thus, the photographer must obtain the prior approval of that person to publish it. Otherwise, it shall be considered as an illegal act violating one's image right. This violation is often considered damaging to the character of the person appearing in the image. That is because such an act may be associated with a denigration and exploitation of one's character.

Publishing someone's photo for denigrating and exploiting his character shall be discussed below:

First: The denigration of one's character through publishing his photo:

There is a debate over whether the photo shall become public when publishing it or presenting it before others. There's a debate over whether the photo shall become public when viewed by one person or indefinite number of people.

Jurists agree that viewing the image by one person or more shall be considered as an infringement of one's privacy or image right. That is because the image shall reveal aspects of one's personal life. Infringing people's privacy right has become easier due to the technological developments in the field of photography. Such developments have enabled people to invade others' privacy right even when they are behind locked doors ${ }^{1}$.

An image representing someone may get published without his approval. However, people may not be able to recognize the person due to the lack of similarity between the bodily and facial features of the person and the counterpart features appearing in the image ${ }^{2}$. In such a case that shall be not be considered an infringement of image right whether there are damages resulting from the act or not. However, in case there's a partial of full similarity between the bodily and facial features of the person and the counterpart features appearing in the image enabling people to recognize the person, the act shall be considered an infringement. That is because the law doesn't seek to protect one's face only. In fact it seeks to protect one's body and bodily features too ${ }^{3}$.

During the hearing sessions, the judge must make sure that that the image represents the plaintiff. In case the judge couldn't do that by himself, he shall ask experts to provide their opinions about that. That is because this kind of dispute is similar to any other kind of disputes. To illustrate more, this dispute involves technical aspects that require the opinions of experts ${ }^{4}$.

That is consistent with a judgment issued by the court of first instance of Amman / the criminal division / which holds No. 1998 / 3234. This judgment was issued due to a newspaper article titled (Homosexuality and drugs in some men's and women's beauty salons). The latter article includes information about interviews conducted with customer of Jordanian saloons. Such information includes rumors and gossip about the infringements occurring in some men's and women's beauty salons. The latter article includes the plaintiff's photo while she was getting her hair done by a worker in a beauty salon. The eyes of the plaintiff in the photo were covered with a black stripe. That implies that the plaintiff is the one accused of practicing such infringements. Witnesses confirmed that the plaintiff could be recognized through the photo. The court decided to pay $6000 \mathrm{JDs}$ for the plaintiff to compensate her for the damages resulting from violating her personality right ${ }^{5}$.

\footnotetext{
${ }^{1}$ Dr. Hisham Mohammad Farid. ibid. p. 105

${ }^{2}$ Dr. Husam Al-Deen Al-Ahwani. ibid. p. 138

${ }^{3}$ Dr. Hisham Mohammad Farid. ibid. p. 107

${ }^{4}$ Dr. Saeed Jaber. ibid. p. 8

${ }^{5}$ A judgment issued by the court of first instance of Amman / the criminal division / No. 1998 / 3234 / Date: 10 / 4 / 2004
} 
Thus, denigration of a character through publishing his image must involve publishing it with information that contrasts that real facts. That applies even if his bodily or facial features were adjusted in the photo. However, consider the act as an infringement, people must be able to recognize the one in the one that the photo represents. That applies whether the photo is taken through a photographic or cinematographic device or a caricature photo maker.

Second: The exploitation of someone's character

The exploitation of someone's character is considered the most significant consequence of the invention of photographic devices. Such an exploitation may involve using someone's photo for advertising. This illegal behavior is carried out to influence people's behaviors through using communication means ${ }^{1}$. The exploitation of someone's image may occur through a positive or negative manner. That shall be discussed below:

1)- The negative exploitation of someone's image for commercial purposes:

This case represents the majority of the cases that involve infringement of someone's privacy and image rights. That is because using people's images in the economic sector is very significant. For instance, using people's images may be used for advertising and marketing products in this sector ${ }^{2}$. There is no doubt that the exploitation of someone's image for advertising without his approval shall cause financial and moral damages to the concerned person. Such moral damages occur when the concerned person doesn't usually allow publishing his photos for adverting with asking him or signing a contract. That applies to celebrities. It should be noted that publishing celebrities' photos for advertising purposes shall cause serious moral damages to those people. As for the financial damage, it occurs when the person is used to gaining earnings from publishing his photos for advertising purposes. That applies to professional models. For instance, publishing a model's photo for advertising purposes without getting his approval shall deprive him from getting a remuneration. That is because the model would have earned a remuneration if the image was published under a contract with his approval ${ }^{3}$.

2)- The positive exploitation of someone's image for commercial purposes:

The positive exploitation of someone's image for commercial purposes involves publishing his image for advertising goods and products under his approval. In addition, many people - especially celebrities, such as: famous athletes, actors, and models - agree to publish their photos that reveal aspects of their personal lives in exchange for money ${ }^{4}$. The law entitles everyone to control the way he uses and benefits from his name, photo and any other aspect of his identity for commercial purposes. That is called (the right of publicity) ${ }^{5}$.

Thus, it can be concluded that exploiting someone's image through publishing it without taking his approval shall be considered as an infringement of his image right. That applies whether that person is a celebrity or from the public. That also applies whether the concerned photo reveals aspects from that person's personal life or not.

\section{The compensation for the damages resulting from violating someone's image right}

The punishment of the ones who infringe others' image right is represented in obliging them to provide a compensation. In this regard, a compensation is considered as a remedial measure that is claimed by the one entitled to object. It is claimed for making up for the damages resulting from infringing one's image right. The

\footnotetext{
${ }^{1}$ Dr. Mohammad Wasel. ibid. p. 351

${ }^{2}$ Dr. Saeed Jaber. ibid. p. 45

${ }^{3}$ Dr. Husam Al-Deen Kamel Al-Ahwani. ibid. p. 140.

${ }^{4}$ Dr. Mamdouh Mohammad Khairy Al-Maslamy. ibid. p. 396

${ }^{5}$ Souvanik Mullick \& Swati Narnaulia: " Protecting Celebrity Rights Through Property Conceptions", National University of Juridical Sciences, Law Review, Kolkata, India, Vol. No. 4, October-December, 2008,p. 616
} 
compensation may be an in-kind or cash compensation. It should be noted that there are certain criteria taken into consideration when determining the value of the compensation.

In the light of the aforementioned, the researcher shall identify the requirements that must be fulfilled for issuing a judgment that obliges the infringer to provide a compensation. The researcher shall identify the compensation forms. He shall identify the way it is estimated. That shall be discussed below:

\section{The requirements that must be fulfilled for issuing a judgment that obliges the infringer to provide a compensation:}

Compensation is one of the results derived from having a civil liability. It is also considered as a remedial measure. It is claimed by the one whose image right is infringed for repairing the damages resulting from the infringement. The latter liability may be a contractual liability. Such a liability shall arise if the person who caused the damage refrained from fulfilling his contractual obligation. Such a liability may also arise if the latter person fulfilled his contractual obligation in a faulty manner that caused damages to the one appearing in the image. However, the liability may be tortious liability rather than contractual. The tortious liability shall arise when someone breaches a duty set by law which obliges all people to refrain from causing damages to others unlawfully. When any of those liabilities arise, the judgment shall be for the favor of the person who suffered from damages. In addition, the court shall issue a judgment obliging the one who caused the damage to provide a compensation ${ }^{1}$.

A compensation lawsuit is considered the judicial mean that ensures showing respect for one's image right by others. Though the latter mean, one shall be entitled to claim for a compensation to make up for the damages resulting from infringing his image right.

In order to issue a judgment that obliges one to provide a compensation, all the elements of (contractual or tortious) liability must exist. These elements are: (fault, damage and causal relationship between them). In other words, there must be a direct relationship between the infringement act and the damage caused. That means that the damage must be resulting from the infringement act. All jurists agree that this general rule applies to the infringement of image right. There is no debate among jurists about that. Thus, there isn't any issue that requires discussion or analysis by the researcher about that.

The researcher shall discuss the requirements that must be fulfilled for issuing a judgment that obliges the infringer to provide a compensation. That shall be discussed below:

\section{The wrongful act (fault) (The electronic fault):}

Through this section, the researcher shall identify the elements of fault (wrongful act) ${ }^{2}$. The researcher shall also address the issue of (electronic fault). That shall be discussed below:

\footnotetext{
${ }^{1}$ Dr. Anwar Al-A'mrousi. The tortious and contractual legalities in the civil law (Elements, co-occurrence of both and compensation). A comparative fundamental study. $1^{\text {st }}$ edition. Al-Feker Al-Jame'i publishing and distribution house. 2004. p. $43-44$

${ }^{2}$ The Egyptian legislator used the word (fault) through article 163 of the Egyptian civil law. However, the Jordanian legislator used an alternative term; (damage) through article 256 of the Jordanian civil law. That latter article states that the following (Any damage caused to others shall oblige the one who causes it to provide a compensation. That applies even if that latter person lacks capacity). Based on the latter article, the Jordanian legislator is influenced by Fiqh (Islamic jurisprudence) in terms of using the term (damage)
} 


\section{First: The elements of fault:}

Most legislators doesn't provide a definition for fault in civil laws. Thus, jurists were held responsible for providing a definition for it. However, there's a debate among jurists about the definition of (fault). The researcher reviewed the definitions that some jurists provide for the term (fault). After such review, the researcher concluded two things, which are listed below:

The first thing: Most jurists believe that the fault is a failure to fulfill an obligation that one has pledged to fulfill earlier.

The second thing: Jurists believe that the meaning of the fault constituting the tortious liability is derived from the meaning of the fault constituting the contractual liability. They define the fault constituting the tortious liability as the failure to fulfill a legal obligation. As for the fault constituting the contractual liability, jurists define it as failure to fulfill a contractual obligation ${ }^{1}$. Faults are often tortious. In the faults constituting the tortious liability, there's no contractual relationship between the one who caused the damage and the one who suffered from it.

The tortious liability arises from failure to show the required duty of care. Showing the duty of care means that one must be watchful and foresee any possible danger to prevent causing any damage to others. In case the one who caused the damage has the capacity to recognize that he committed a breach, this breach shall be considered a fault. When committing such a fault, the tortious liability shall arise ${ }^{2}$.

That means that a fault is constituted from two main elements. The first element is the physical element (i.e. the act of infringement). As for the second element, it is the mental element (cognition). That shall be illustrated below:

1)- The first element: The physical element (i.e. the act of infringement)

In Fiqh Islamic jurisprudence and the Jordanian civil law, the counterpart expression used for referring to (fault) is (wrongful act). The expression (wrongful act) means that the act committed by the infringer is unlawful ${ }^{3}$.

The infringement act occurs when the infringer crosses the lines that he is obliged to refrain from crossing. In this regard, this act is represented in the unlawful infringement of someone's image right. That applies whether this obligation is set by a contract, or a law. For instance, the law obliges one to respect others' rights and refrain from infringing their rights. That applies whether the infringement occurs intentionally or unintentionally ${ }^{4}$. Hence, committing a negligent act or a minor fault by the infringer (i.e. the photographer) shall make him held liable for infringing others' image right. To be specific, the one who infringes someone's image right with intending to cause damage shall be held liable. Such infringement is represented in capturing or publishing someone's photo without his approval and / or in a way that violates the terms of the contract. It should be also noted that the one who infringes others' image right shall be held liable even if he didn't cause the damage intentionally. That applies in case the infringer committed the infringement act due to his lack of watchfulness or foresight ${ }^{5}$.

\footnotetext{
${ }^{1}$ Dr. Abed Al-Razeq Al-Sanhouri. Al-Waseet for elaborating the civil law. The first volume. Al-Ma'aref publishing and distribution house. Alexandria. 2001. p. 879

${ }^{2}$ Dr. Mohammad Wahid Al-Deen Sewar. General orientations about the Jordanian civil law: A comparative study between the Jordanian civil law, Fiqh (Islamic jurisprudence) and Arab blogs. Dar Al-Thaqafeh publishing and distribution house. Amman. 1996. 130

${ }^{3}$ Notes for elaborating the Jordanian civil law. Prepared by the Technical Office of Jordan Bar Association. $2^{\text {nd }}$ edition. $1^{\text {st }}$ volume. Al-Tawfiq printing house. Amman. 1985. Article 257. p. 281.

${ }^{4}$ Dr. Husam Al-Deen Kamel Al-Ahwani. ibid. p. 439

${ }^{5}$ Dr. Mamdouh Mohammad Khairy Al-Maslamy. ibid. p. 425
} 
When the infringement act is evaluated to identify how deviant it is, it must be evaluated objectively rather than subjectively. Thus, the infringer's behavior must be compared to the behavior of someone else who may show moderate watchfulness and care under the same conditions ${ }^{1}$.

2)-The second element: Mental element (Cognition):

That means that the one who captured or published the photo must be able to recognize between good and bad behaviors. In other words, he must be able to recognize that what he is doing shall cause damages to others. That's why children and mad people are not held liable for their wrongful acts which cause damages to others. The same applies even if their acts involve infringements of others' rights and failure to fulfill their obligations ${ }^{2}$.

To sum up, an infringement of someone's image right - which is a personality right - might occur. Such an infringement may be presented in capturing or publishing someone's photo without his prior approval. In case the infringement act has been committed intentionally or non- intentionally, the infringer shall be obliged to provide a compensation to make up for the damages. The one who suffered from damages doesn't have to prove the presence of the liability elements (i.e. fault, damage and causal relationship between them). These elements shall be considered present just by having the image captured or published, unless the infringer (the photographer) proved that there is a reasonable justification or force majeure.

\section{Second: The electronic fault:}

An electronic fault may be called an (electronic wrongful act). There is no doubt that the electronic fault is carried out at a distance from the people whose right is infringed. Due to the nature of this act, those people often do not recognize immediately that their right has been infringed. Hence, the detection of this kind of infringements is harder that the detection of other kinds of infringements. In addition, it may be difficult to retrieve that data (image) that others have hacked. Thus, the hackers shall feel free to utilize the data and images they hacked and benefit from them.

In addition, it is difficult to identify the identity of the one who committed the electronic faults. It is also difficult to identify the time of their occurrence. That is because giving an electronic order goes through several stages. In addition, the one who suffered from damages shall experience a great difficulty in proving the presence of an electronic fault. That is because it's very difficult to verify the identity of the one who committed the electronic fault. The presence of an electronic fault may be proved through tapes, CDs, and microfilms.

There is a debate among jurists about the one considered liable for having the photo published. In other words, there is a debate over which ones should be held liable in case the image right is infringed on the web. That is because the web adopts a decentralized approach. Thus, there are many operators. However, there is no preset regulations for specifying the operators' roles and duties. When the damage occurs, the lawsuit shall not filed against the guardian (i.e. internet service provider). In fact, the law shall seek searching for the one who committed the infringement and proving that he committed the fault ${ }^{3}$.

However, the internet service providers (ISPs) are still considered liable for such electronic infringements. For instance, many liability lawsuits have been filed against them to provide a compensation for the damages caused by data got published on the web. That applies whether the damage is caused to the one who created the data or others. That is because the internet service provider is the only one who have real authority to control the data published on the web. He is also authorized to allow or prevent publishing and transmitting data through the web.

${ }^{1}$ Dr. Abed Al-Razeq Al-Sanhouri. ibid. p. 785

2 Dr. Anwar Al-A'mrousi. ibid. p. 52

${ }^{3}$ Dr. Ayed Raja Al-Khalayleh. The electronic tortious liability and the liability arising from misusing the computer and the internet. A comparative study. $1^{\text {st }}$ edition. Dar Al-Thaqafeh publishing and distribution house. Amman. 2009. p. 243 - 244 
Thus, the internet service provider is obliged to comply with the rules of the law that concern one's image, personal life, copyright and publishing rights ${ }^{1}$.

Thus, in case one's image right was infringed, the internet service provider (ISP) shall be held liable. That is because he refrained from taking the necessary measures when warned by his customers about the unlawfulness of the images published by users.

Under the general rules of the law, the civil liability resulting from a personal conduct shall arise only when the elements of civil lability are present. These elements are: (fault, damage and causal relationship between them). In case the judiciary requires proving the presence of the electronic fault and the identity of the one who committed it, it shall be semi-impossible for the liability to arise. That is attributed to the complex nature of wrongful act (i.e. the electronic fault). That means that the existing legislations are not capable to keep up with the technological and technical developments in this regard.

Thus, the researcher believes that a judiciary should not be strict in terms of requiring the presence of the liability elements in case a photo was published on the web without a prior approval. He also recommends considering the fault present just by having the photo published on the web. The researcher also believes that the internet service provider (ISP) must be held liable in all the cases that involve having people's images published on the web without their approval.

Let's assume that a judiciary consider ISPs not responsible for monitoring the data published on the web. In such a case, all ISPs shall refrain from monitoring the data published on the web. That shall promote the spread of illegal content on the web. It shall also promote the spread of infringements of people's image and personal life rights.

Damage (electronic damage):

Several articles address the issue of damage. Such articles include article 48 of the Jordanian civil law and article 50 of the Egyptian civil law. Such articles also include article 9 of the French civil law. Some Egyptian jurists ${ }^{2}$ believe that the latter two articles indicate that the occurrence of the infringement act isn't enough by itself for holding the infringer liable. In fact, the infringement act must cause damages.

However, some jurists and the French judiciary ${ }^{3}$ believe that the damage shall be presumed by having an infringement act. The latter act is represented in capturing or publishing someone's photo without having his prior approval. That applies whether the infringement act was committed intentionally or non-intentionally (i.e. due to negligence $)^{4}$. When issuing a judgment that obliges the infringer to provide a compensation for the damages, the French judiciary exempts the one suffering from damages from proving the occurrence of the damage and its value $^{5}$. Thus, the occurrence of the damage is presumed and the one suffering from damages shall be exempted from proving the occurrence of the damage ${ }^{6}$.

However, in order for the plaintiff to protect his interests, he should provide evidence about the value of the damages that he must get a compensation for. For instance, when determining the value of the compensation required to cover the damages, the judge takes one factor into consideration. This factor is represented in the value of the damages resulting from the infringement act ${ }^{7}$. The judge has a discretionary authority to decide whether the

\footnotetext{
${ }^{1}$ Dr. Ayed Raja Al-Khalayleh. ibid. p. 245

${ }^{2}$ Dr. Husam Al-Deen Kamel Al-Ahwani. ibid. p. 436

${ }^{3}$ Dr. Mamdouh Mohammad Khairy Al-Maslamy. ibid. p. 453 - Dr. Saeed Jaber. ibid. p. 129

${ }^{4}$ Dr. Mustafa Ahmad Hijazi. ibid. p. 249

${ }^{5}$ Mamdouh Khalil Al-Bahar. ibid. p. 445

${ }^{6}$ Mamdouh Mohammad Khairy Al-Maslamy. ibid. p. 451

${ }^{7}$ Mamdouh Khalil Al-Bahar. ibid. p. 246
} 
damage is existent or non- existent. This is a substantive issue which the court of cassation doesn't have authority to control. However, there are certain conditions that must be fulfilled in the damage to consider the damage existent. The fulfillment of these conditions is subjected to the control of the court of cassation ${ }^{1}$. These conditions shall be identified in other paragraphs. The court of cassation is entitled to control the way the value of the compensation is estimated and the way the incidents were considered under the provisions of the law ${ }^{2}$.

The researcher shall address two types of damages; the physical and moral damages. He shall also address electronic damages. These things are discussed below:

First: The physical damages:

These damages refer to the damages that make one incur financial losses. This kind of damages involves the damages affecting one's body, or money. It also involves the damages affecting one's honor leading him to incur a financial loss ${ }^{3}$. The physical damage involves two elements: the damages that have been already incurred and the earnings that have been missed ${ }^{4}$. Most of the image right-related lawsuits that involve physical damages are filed for exploiting the image for commercial purposes. In the latter lawsuits, the image right is an independent right that is different from personal life rights ${ }^{5}$.

In order to hold the offender liable, the damage must be existent. That means that the damage must have occurred in the present or shall definitely occur in the future ${ }^{6}$. That applies whether the judge is or isn't able to estimate the value of the future damages. In case he's able to issue a judgment that makes up for all the damages, he must issue a judgment immediately. For instance, an infringer may take the photo of a female celebrity without her approval. He may have the intent to publish the photo in the future and exploit it for commercial purposes. In such a case, the judge is authorized to issue a judgment obliging the latter offender to provide a compensation for the damages that have already occurred. In case the photo was published or exploited, the judge shall issue another judgment that involves an estimation of the value of the overall damages. Under the latter judgment, the offender shall be obliged to provide a compensation?

The damage may be represented in depriving someone from an opportunity through which he could have got earnings. In other words, the damage may represented in missing an opportunity, provided that this opportunity must be existent and could be utilized ${ }^{8}$. According to most jurists ${ }^{9}$, missing an opportunity is associated with a potential damage. That is because the opportunity in this regard shall make one incur financial losses which could be estimated. Thus, the offender must provide a compensation. For example, an actress may let a photographer take a photo for her for advertising something. In case the photographer exploited her photo for commercial purposes without her approval, then he deprived her from an opportunity to get earnings. In such a case, the actress is entitled to get a compensation for the opportunity she has missed ${ }^{10}$.

\footnotetext{
${ }^{1}$ Dr. Mohammad Hussein Mansour. ibid. p. 332

${ }^{2}$ Mustafa Ahmad Hijazi. ibid. p. 255

${ }^{3}$ Dr. Ahmad Hassan Al-Hyari. ibid. p. 127

${ }^{4}$ Article 206 of the Jordanian civil law - Article 221 of the Egyptian civil law

${ }^{5}$ Mustafa Ahmad Hijazi. ibid. p. 258

${ }^{6}$ Dr. Anwar Al-A'mrousi. ibid. p. 235

${ }^{7}$ Pursuant to article 268 of the Jordanian civil law and articles $(170,171)$ of the Egyptian civil law

${ }^{8}$ Mohammad Wahid Al-Deen Sewar. ibid. p. 154

${ }^{9}$ Dr. Abed Al-Razeq Al-Sanhouri. ibid. p. 817

${ }^{10}$ Dr. Saeed Jaber. ibid. p. 26
} 
Second: The moral damage:

Article 1382 of the French civil law deals with the issue of damages. In the latter article, the legislator doesn't distinguish between the types of damages (i.e. between the moral and physical damages). As for article $267^{1}$ of the Jordanian civil law, it states that the damage is moral when it affects one's freedom, honor, reputation, social status, or financial position.

However, the researcher believes that the moral damages resulting from infringing someone's image right may be represented in damages other than the ones mentioned in article 267 of the Jordanian civil law. For instance, the researcher believes that the moral damages resulting from infringing someone's image right may include feeling ashamed when revealing some aspects related to family and personal life. The researcher also believes that moral damages also include psychological suffering resulting from revealing aspects related to his personal life.

The researcher believes that article 267 of the Jordanian civil law aims to elaborate article 48 of the latter law. That is because the latter article includes a general provision for protecting personality rights. Thus, the moral damages are not limited to the damages affecting one's body, honor, emotions, and reputation. In fact, moral damages involve all the damages that affect the moral aspects of one's life $^{2}$. Such damages are considered moral whether they result from infringement of someone's lawful interests or financial or non- financial rights (e.g. privacy, image and name rights).

In case a photo was published without the knowledge or approval of the one appearing in it, this act represents an infringement of his personality rights. This act shall cause him psychological pain and suffering. In such a case, the act shall be considered damaging to one's moral interests. Thus, one shall be entitled to file a lawsuit to protect his moral interest from such an infringement. In other words, it is not necessarily to have an infringement of financial interests to become entitled to file a lawsuit. In fact, if one's moral interests only are infringed, he shall be entitled to file a lawsuit. The moral interests are considered more important than the financial ones by many jurists ${ }^{3}$.

The amount of the moral damage is evaluated by the judge under his discretionary authority. However, that doesn't eliminate the need to provide a comprehensive definition for the expression (moral damage) in the law. Such a definition should involve all the things that may cause psychological harm in case an infringement occurred ${ }^{4}$.

Although article 267 of the Jordanian civil law restricts moral damages to certain types of damages, the researcher believes that such restriction shouldn't be done. To be specific, the researcher believes that moral damages in laws should be unrestricted as it is the case in the French and Egyptian civil laws.

Under article 48 of the Jordanian civil law, the infringer must provide a compensation that make up for all the moral or financial damages resulting from infringing a personality right. That applies to the infringement of others' image right. Similar to faults, the presence of the damage shall be presumed just by having the photo captured or published without the approval of the one appearing in the image. In addition, the one appearing doesn't have to prove the presence of the damage ${ }^{5}$.

Similar to the physical damage, the moral damage must be a personal damage. The compensation for a moral damage can't be seized by others when it's not given by the infringer yet, unless there is an agreement that requires

\footnotetext{
${ }^{1}$ It is similar to article 222 / 1 of the Egyptian civil law

${ }^{2}$ Dr. Mohammad Wasel. ibid. p. 20

${ }^{3}$ Dr. Saeed Jaber. ibid. p. 127

Dr. Ayed Raja Al-Khalayleh. ibid. p. 142

${ }^{4}$ Bairk Fares Al-Jboury. ibid. p. 343

${ }^{5}$ Dr. Mustafa Ahmad Hijazi. ibid. p. 293 - 5 Dr. Saeed Jaber. ibid. p. 127
} 
so or the debtor requested that ${ }^{1}$. Such a compensation may be seized by others in case a final judgment was issued in this regard ${ }^{2}$.

Third: Electronic damage:

Based on the aforementioned, there are several conditions that must be met in the damage in order for the civil lability to arise. In other words, these conditions must be met in the damage to oblige the offender to provide a compensation for the damage he caused. Such conditions are: 1)- The damage must be existent; 2)-The damage must be direct; 3)- The damage must be resulting from an infringement of an acquired right or resulting from an infringement of a lawful interest and 4)- The damage must be a personal damage.

These conditions are applicable to electronic faults, except for the third condition. The latter condition means that the damage must be a direct result of the fault (wrongful act). In most the cases that involve damage resulting from misusing the internet, the damages are not a direct result of the fault. Such indirect damages go through several changes, stages, and transitions ${ }^{3}$. Thus, requiring to fulfill this condition is unfair. In such a case, the ones who suffered from damages resulting from infringing their rights shall not be entitled to claim for a compensation for the damages.

In some cases related to misusing the web, it is difficult to prove that a damage has occurred. That is attributed to the use of many technical means for tracking the personal information of internet users. A cookie message is considered the most prominent mean. The latter mean is used when a user enters a specific website willingly. The latter website shall ask the user to provide his personal information in the aim of exploiting it later. Such information may include the user's photo. In other words, the user shall provide his information without knowing that he's being tricked ${ }^{4}$. However, such manipulation shall make the user experience psychological suffering and pain. This manipulation shall be considered damaging to his emotions and freedom of choice. Such damages are considered moral damages ${ }^{5}$.

Thus, the laws mustn't restrict damages to certain types of damages. In fact, laws must adopt a broad definition for the meaning of the term (damage). Such a definition must consider damage as a direct result of fault. Thus, the damage must be presumed just by having the photo published without a prior approval. When proving the presence of a fault and a damage, the presence of a casual relationship between them shall be presumed for the favor of the plaintiff. The offender can prove that this relationship is invalid due to a compelling reason that he couldn't have controlled.

\section{Forms and Estimation of Compensations}

A person may infringe someone's image right. In case it was proved it was proved that the infringer is responsible for the (moral or financial) damages resulting from the infringement, the judge must oblige such an infringer to provide a compensation. The compensation must make up for the damages caused by his infringement act. Compensation shall also enable one to repair the damages. The compensation may be in-kind or cash. However, compensations are often cash. In other words, compensations are provided for alleviating the damages as much as possible. They are also provided for restoring things to the way they were before the occurrence of the infringement. That is why in-kind compensations are provided. In case, the infringer couldn't provide an in-kind compensation, he shall be obliged to provide a compensation that serves as an alternative for the in-kind compensation. Such a compensation may be represented in non- monetary compensation or monetary compensation. The non- monetary compensation may be represented in performing certain works. As for the

\footnotetext{
${ }^{1}$ Article 222 / 1 of the Egyptian civil law

${ }^{2}$ Article 267 / 2 of the Jordanian civil law

${ }^{3}$ Dr. Ayed Raja Al-Khalayleh. ibid. p. 142

${ }^{4}$ Kendah Al-Shamat. ibid. p. 575

${ }^{5}$ Dr. Ayed Raja Al-Khalayleh. ibid. p. 143 - Dr. Mohammad Hussein Mansour. ibid. p. 333
} 
monetary compensation, it is represented in cash compensation. That is stated in article 269 / 2 of the Jordanian civil law ${ }^{1}$.

The researcher shall shed a light on in-kind compensation. He shall also shed a light on the judge's authority in terms of issuing a judgment obliging the infringer to provide an in-kind compensation. Then, the researcher shall shed a light on the compensation that serves as an alternative for the in-kind compensation. Then, the researcher shall also shed a light on the applicability of the statute of limitations on the compensation lawsuits. These things shall be discussed below:

\section{In-kind compensations and the judge's authority in terms of issuing a judgment obliging the infringer to} provide such compensations:

The in-kind compensation refers to the process of restoring things to the way they were before the occurrence of the infringement which resulted in damages. Such restoration is carried out by the infringer. Through such restoration, the infringer shall restore things to the way they were before as if the infringement act has never occurred $^{2}$.

The in-kind compensation is considered the best method for making up for someone's damage and the impacts resulting from the damage. The same applies in case there's an infringement of someone's image right for commercial purposes, especially if the damage is resulting from failure to comply with contractual obligations (contractual liability). Such a failure may be represented in the failure to deliver the copies of the photographs which were agreed upon in the contract.

The commercial exploitation of someone's photo may be represented in some cases of tortious liability. Such cases may include publishing the photo of a celebrity (e.g. famous actress) without having a contract nor her prior approval ${ }^{3}$. In such a case, the compensation serving as an alternative for the in-kind compensation is the best compensation.

\section{The compensation serving as an alternative for the in-kind compensation}

The one whose image right is infringed may not claim an in-kind compensation. The latter compensation may be considered inappropriate for making up for the damages of the plaintiff. That applies in case the damages are moral. In such cases, the judge shall oblige the infringer to provide a compensation that serves as an alternative for the in-kind compensation. Such a compensation must have a value that is equivalent to the value of the damages resulting from the infringement $\mathrm{act}^{4}$. This compensation may be represented in non- monetary compensation or monetary compensation. The non- monetary compensation may be represented in performing certain works. As for the monetary compensation, it is represented in cash compensation. That shall be discussed below:

First: Non-monetary compensation:

\footnotetext{
${ }^{1}$ Article 269 / 2 of the Jordanian civil law states that the court shall estimate the value of the compensation in cash. However, the court is entitled to oblige the infringer to restore things to the way they were before the occurrence of the infringement or oblige the offender to perform certain works. Such works must serve as a compensation for the damages resulting from the wrongful act. That shall be decided by the judge based on the circumstances and upon the request of the one who suffered from the damages.

The same is adopted by article 172 / 2 of the Egyptian civil law

${ }^{2}$ Dr. Sa'doon Al-A'mery. Compensation for the damages in cases of tortious liability. The Center for Research in law. The Ministry of Justice. Baghdad. 1981. p. 149

${ }^{3}$ Dr. Saeed Jaber. ibid. p. 131

${ }^{4}$ Dr. Mohammad Wahid Al-Deen Sewar. ibid. p. 234
} 
That means that the judge shall oblige the infringer to perform certain works. That is done for making up for the damages. This compensation is different from the cash and in-kind compensations. The non-monetary compensation may be the best choice in some circumstances. It may be the best choice for protecting the interests of the plaintiff ${ }^{1}$. The Non-monetary compensation has various forms. The legislator didn't restrict non-monetary compensation to specific forms ${ }^{2}$. Such forms may include: issuing a judgment for the favor of the plaintiff. Such forms include obliging the infringer to apologize and return the expenditures. The most important forms of nonmonetary compensation include obliging the infringer to pay delay fines; and publishing the judgment of condiment in a daily newspaper. These things are discussed below:

1)- Publishing the judgment of condiment in a daily newspaper:

In exceptional cases, the judge may issue a judgment that obliges the infringer to publish the judgment condemning him at his own expense. That shall participate in making up for the damage in an appropriate manner ${ }^{3}$.

2)- Obliging the infringer to pay a delay fine to ensure that the judgment shall get published:

The judge may issue a judgment that obliges the infringer to pay a delay fine in case he refrained from fulfilling out his obligation or delayed such fulfilment. When estimating the value of such a fine, the judge must take into consideration the debtor's financial position and how stubborn he is. When estimating the value of such a fine, the judge shouldn't take the value of the damage into consideration ${ }^{4}$. In some cases, the longer the period of delay, the higher the value of the delay fine shall be. That may be decided by the judge to fulfill the goal sought from enforcing such a fine. Such a goal is represented in obliging the infringer to fulfill his obligation. This obligation is represented in. publishing the judgment condemning him at his own expense ${ }^{5}$.

The Jordanian legislator didn't provide a legal text that entitles the judge to oblige the infringer to pay a delay fine. As for the Egyptian legislator, he enacted such a text through articles $(213-214)$ of the Egyptian civil law. As for French civil law, it doesn't include an article that deals with such a fine. However, the French judiciary adopts this punishment and entitles the judge to make the offender pay such a fine for each day of refraining from publishing the judgment. That is done in the aim of obliging the offender to fulfill his obligation ${ }^{6}$.

Second: Monetary Compensation:

It is represented in the amount of money estimated by the judge to make up for the damages. This amount of money must be paid by the infringer who caused the damage. This type of compensation is considered the most prominent and widely used type of compensation. It is considered the most suitable type of compensation for making up for the damages resulting from the fault (the wrongful act). It should be the judge's first choice in case the civil liability arises ${ }^{7}$. Thus, that means that the judge is entitled to issue a judgment obliging the infringer to provide a monetary compensation if that was justified. That applies to all the cases that did not fulfill the requirements of non-monetary or in-kind compensation. The infringer may be obliged to provide a monetary compensation that is associated with a non-monetary or in-kind compensation ${ }^{8}$.

\footnotetext{
${ }^{1}$ Notes for elaborating the Jordanian civil law / article 269 / Vol. 1. ibid. p. 301

${ }^{2}$ Article 269 / 1 of the Jordanian civil law

${ }^{3}$ Dr. Nicola Fatoush \& Andre Bartran. Personal life and image rights. Sader Nasheroon Library. Beiruit. 2003. p. 279

${ }^{4}$ Dr. Anwar Sultan. Reasons for the rise of liability under the Jordanian civil law. $3^{\text {rd }}$ edition. The University of Jordan. Amman. 2000. p. 402

${ }^{5}$ Dr. Sa'doon Al-A'mery. ibid. p. 156

${ }^{6}$ Dr. Mamdouh Khalil Al-Bahar. ibid. p. 450

${ }^{7}$ That is according to article 269 / 2 of the Jordanian civil law and article 172 / 2 of the Egyptian civil law

${ }^{8}$ Dr. Anwar Sultan. ibid. p. 404
} 
The researcher believes that the monetary compensation is essential when any personality right (e.g. image right) is infringed. It is considered so because the damage is presumed just by having the photo published and things can't be restored to the way they were before the infringement.

Thus, the researcher shall identify the methods used for estimating the value of damages. He shall also identify personal and substantive considerations that are taken into consideration when estimating the value of the compensation. That shall be identified below:

1)- The methods used for estimating the value of compensation:

In terms of estimating the value of the compensation, there is a fixed rule adopted by the (French, Egyptian and Jordanian) civil laws. Under this rule, the compensation should make up for the value of the damages that have been already incurred and the earnings that have been missed. However, such damages and missed earnings must be the result of the fault (wrongful act). Under this rule, the compensation must make up for the moral damage caused by the infringement ${ }^{1}$.

There is no difficulty in estimating the value of the monetary compensation required for making up for the physical damages caused by the infringement of image right. However, it is difficult to estimate the value of the compensation required for making up for a moral damage in a specific case. It should be noted that such a difficulty shouldn't prevent the one suffering from damages from obtaining a compensation. All jurists and judicial bodies agree that the financial compensation is considered the most important mean for making up for the damages completely or alleviate them as much as possible ${ }^{2}$. That is because providing a certain amount of money shall help the one suffering from damages in carrying out several measures. Through such measures, he shall be able to perform his usual activities, enjoy life, and overcome his pain and suffering ${ }^{3}$.

\section{2)- Substantive and personal considerations:}

In the cases involving a damage, the French judiciary makes no distinction between the infringement of financial rights and the infringement of moral rights. However, it is noticed that the French courts takes several substantive and personal considerations into consideration when estimating the value of a compensation in the cases involving infringement of personal life and image rights ${ }^{4}$. The personal considerations include the following:

\section{A)- How famous the plaintiff is:}

In case a celebrity's image right was infringed for commercial purposes, the financial damage resulting from such damage would be high. Thus, the value of the compensation shall be high too. However, in case the image right of someone from the public was infringed for such purposes, there wouldn't be any financial damage resulting from such infringement. Thus, the value of the compensation wouldn't be high.

In addition, in case a celebrity's image right was infringed, he / she shall be entitled to get a compensation for the moral damage resulting from the infringement. Such a damage may be represented in the form of psychological

\footnotetext{
1 Dr. Anwar Sultan. ibid. p. 400

2 Notes for elaborating the Jordanian civil law. Vol. 1. (Article 267). ibid. p. 297

${ }^{3}$ Dr. Sa'doon Al-A'mery. ibid. p. 154

${ }^{4}$ Dr. Nicola Fatoush \& Andre Bartran. ibid. p. 273
} 
suffering and pain. That applies in case the photos were published without the prior approval of the concerned celebrity. It also applies in case the celebrity's photographer violated the terms of the contract ${ }^{1}$

B)- The statements and the behavior of plaintiff and his collusion with media:

For instance, there are celebrities who aren't much famous and desire to be so. Thus, in cahoots with some newspapers, they make fabricated major conflicts with others. The information about such conflicts are published through these newspapers. That is done in the aim of becoming more famous. It is also done to gain much profits resulting from the increasing sale volume of the newspaper copies which include the published photo. In such a case, the French judiciary seeks to alleviate the compensations enforced on such newspaper. Such compensations are enforced to make up for the damages that have already occurred and the opportunities that have been missed. The compensation involves a nominal amount of money. In France, such a compensation is called (a single nominal frank $)^{2}$

C)- Presuming that someone shall tolerate publishing his photo without his approval because he has published it earlier:

The plaintiff may have published the concerned photo earlier. However, that doesn't entitle to publish it again by anyone without his approval. That applies whether the photo shall get published in the same newspaper or another one. In case the photo got published again without his approval, the court shall not consider the damage resulting from such infringement a great damage. In addition, the judiciary shall consider such an infringement as a minor infringement. Thus, the judiciary shall oblige the infringer to provide a nominal compensation or a compensation of low value ${ }^{3}$.

As for the substantive considerations, they include the following ones:

A)- How public the mean used for publishing the photo is

For instance, the publication that published the photo may be distributed within a specific region or within several regions. In case the publication is distributed within several regions, the damage shall be considered a great damage. Thus, the value of the compensation shall be very high. For instance, if a photo got published on the World Wide Web, the damage shall be considered a global damage. Thus, the value of the compensation shall be very high ${ }^{4}$.

B)- The type and specialty of the publication which published the photo:

The judiciary takes into consideration the type of the publication which published the photo. For instance, the publication may be issued in a daily, weekly or monthly basis. In addition, the judiciary takes into consideration the specialty of the publication. For instance, the publication may be social, political, commercial or etc.... In addition, the judiciary takes into consideration the nature of the commercial exploitation of the photo ${ }^{5}$.

\footnotetext{
${ }^{1}$ Kendah Al-Shamat. ibid. p. 523

${ }^{2}$ Dr. Nicola Fatoush \& Andre Bartran. ibid. p. 276

${ }^{3}$ Dr. I'smat Ahmad Al-Bahji. ibid. p. 560

${ }^{4}$ Dr. Saeed Jaber. ibid. p. 162

${ }^{5}$ Dr. Nicola Fatoush \& Andre Bartran. ibid. p. 279
} 
C)- The image size, and the place and manner of its publication:

The photo may have been published on the cover page, or other pages of the publication. That is taken into consideration by the judiciary. In addition, the judiciary takes into consideration the number of copies that have been sold ${ }^{1}$.

Sub-section 3: The applicability of the statute of limitations on the compensation lawsuits

The statute of limitations isn't applicable to the acquisition of image right nor the deprivation of one from it. This is one of the characteristics of the latter right. However, that doesn't mean that the lawsuits of liability arising from infringing such a right can't be dismissed after a certain limitation period. In fact, the latter lawsuits are governed by a specific limitation period. Such periods are specified in the examined legislations.

Under the French law, the lawsuit shall be dismissed in case they were filed after 30 years starting from the date on which the infringement has occurred. That is based on the general rule mentioned in article (2260) of the French civil law².

One may commit one of the infringements listed in article (35) of the French press law issued on $29 / 7 / 1881$. These infringements are related to libels and slanders. In this case, the limitation period of the plaintiff for filing a lawsuit is (three months). This period starts from the date on which the concerned infringements occurred. The latter law deals with the lawsuits related to libels and slanders. Such infringements involve the publication of a photo that is considered damaging to that person's reputation and honor. Under article (9) or article 1382 of the French civil law, the latter person is not entitled to claim for a compensation after the latter duration passes ${ }^{3}$.

One may commit one of the offenses mentioned in article (226/1) and article 266 / 2 of the new French criminal law of 1994 and a lawsuit is filed against him. The latter articles condemn the ones who take someone's photo in a private place through a remote camera without a prior approval. They also condemn the ones who carry out photographic montage works without a prior approval. Under the rules of the French criminal procedure law, the limitation period of such lawsuits is three years starting from the date on which the person acknowledged that his photo was captured or adjusted through photographic montage.

Article 272 of the Jordanian civil law states the following: (1- The lawsuit of liability arising from a wrongful act may not be filed after three years starting from the date on which the plaintiff acknowledged the occurrence of the damage and the identity of the one who caused it. 2)- In case the latter lawsuit deals with a beach of the criminal law and still can be heard after the aforementioned period under the criminal procedures law, then this liability lawsuit shall be heard. 3)- The lability lawsuit shall not be heard in case 15 years passed starting from the day on which the wrongful act has occurred). Under all circumstances, the public interest lawsuits and the personal interest lawsuits (civil lawsuits) shall not be heard after 3 years starting from the date on which the offense has occurred. That applies in case the lawsuit wasn't filed (article 339 of the Jordanian criminal procedures law)).

Let's assume that the statute of limitations isn't applicable to the lawsuits of liability arising from infringing someone's image and private life rights. That shall lead to undesirable consequences that are damaging to the plaintiff himself. For instance, it shall make people remember a photo that has been forgotten long time ago. In addition, such non-applicability shall enable the plaintiff to keep threating the infringer of filling a lawsuit.

\footnotetext{
${ }^{1}$ Dr. Mamdouh Khalil Al-Bahar. ibid. p. 452

${ }^{2}$ Dr. Saeed Jaber. ibid. p. 135

${ }^{3}$ Dr. Nicola Fatoush \& Andre Bartran. ibid. p. 258
} 
However, the infringer may have regretted doing his deed which he did due to his lack of watchfulness or awareness.

Most jurists and judicial bodies support the applicability of the statute of limitations on the lawsuits filed for infringing a personality right. The researcher supports this orientation. The same is set by the general rules of civil liability. That applies to the lawsuits involving an infringement of image right. In other words, under the general rules of civil liability, the statute of limitations is applicable to the lawsuits involving an infringement of others' image right.

\section{Results and Recommendations:}

It was found that image right refers to the right of any natural person to object to the creation and publication of his image without getting his prior approval. There is no difference between creating the image through drawing it on paper, glass, or fabric, or using the modern technological devices, such as: the photographic devices. It was found that image right is a personality right. That applies whether it is considered an independent right or one of the privacy rights.

The researcher concluded several results and suggested several recommendations. These results and recommendations are listed below:

1)- It was found that one's image right is protected by the general provision set in article 48 of the Jordanian civil law and article 50 of the Egyptian civil law. These articles deal with personality rights. However, the Jordanian and Egyptian legislators must adopt the same approach adopted by the French legislator. That is represented in adjusting the latter articles to protect the image right as an independent right. That must be done due to the significance of the latter right.

2)- Article 9 of the French civil law seeks protecting the personal life right only. It isn't enough for the Arab legislator to enact articles that deal with the protection of the latter right only. In fact, the Arab legislator should enact articles that protect one's image right explicitly. Such articles must involve cases in which the photo reveals aspects of one's personal life. That should be done because personal life rights involve a variety of rights

3)- The Arab legislator must enact legislations for protecting one's image right from electronic crimes. Such protection must protect the transmission of electronic data (including electronic images) through the web from any infringement. Such legislations must be enacted with taking the homeland security into consideration

5)- Article (267 / 1) of the Jordanian civil law must be adjusted. That is because the moral damages resulting from the infringement of image right or another personality right shouldn't be restricted to the damages affecting one's reputation and social status. In fact, the latter article must involve all the damages affecting one's personal life aspects or causing psychological suffering. As it is done by article 222 of the Egyptian civil law, article (267 / 1) of the Jordanian civil law must involve the damages constraining one's ability to control the way his personality aspects (e.g. photo) are utilized

\section{References written in Arabic Language:}

1. Notes for elaborating the Jordanian civil law. Prepared by the Technical Office of Jordan Bar Association. 2nd edition. 1st volume. Al-Tawfiq printing house. Amman. 1985.

2. Dr. Anwar Al-A'mrousi. The tortious and contractual legalities in the civil law (Elements, co-occurrence of both and compensation). A comparative fundamental study. 1st edition. Al-Feker Al-Jame'i publishing and distribution house. 2004. p. $43-44$ 
3. Dr. Anwar Sultan. Reasons for the rise of liability under the Jordanian civil law. 3rd edition. The University of Jordan. Amman. 2000. p. 402

4. Bairk Fares Al-Jboury. Personality rights and its civil protection: A comparative study: Al-Kotob AlQanuniah distribution and publishing house. Cairo. 2009. p. 108

5. Dr. Husam Al-Deen Kamel Al-Ahwani. One's right to show respect for his private life (Privacy right): A comparative study. Al-Nahda Al-Arabeya publishing and distribution house. Cairo. 1978. p. 160

6. Dr. Hasan Keerah. An introduction to law, specifically the Lebanese and Egyptian laws. The second section: the general theory of rights. Makawi Library. Beirut. 1977. p. 574

7. Dr. Sa'doon Al-A'mery. Compensation for the damages in cases of tortious liability. The Center for Research in law. The Ministry of Justice. Baghdad. 1981. p. 149

8. Dr. Saeed Jaber. Image protection right. Al-Nahda Al-Arabeya distribution and publishing house. Cairo. 1986. p. 14

9. Dr. Ayed Raja Al-Khalayleh. The electronic tortious liability and the liability arising from misusing the computer and the internet. A comparative study. $1^{\text {st }}$ edition. Dar Al-Thaqafeh publishing and distribution house. Amman. 2009. p. 243 - 244

10. Dr. Abed Al-Razeq Al-Sanhouri. Al-Waseet for elaborating the civil law. The first volume. Al-Ma'aref publishing and distribution house. Alexandria. 2001. p. 879

11. Dr. Abed Al-Hadi Fawzi Al-Awadi. The general theory of rights. . Al-Nahda Al-Arabeya publishing and distribution house. Cairo. 2006. p. 34

12. Dr. I'smat Ahmad Al-Bahji. Protecting one's right to show respect for his personal life under human rights and civil liability. Al-Jame'a Al-Jadida publishing and distribution house. Alexandria. 2005. p. 125

13. Kendah Al-Shamat. One's right to have a personal life. PhD dissertation. Faculty of law. Damascus University. 2005. p. 177.

14. Dr. Mohammad Wasel. Personality rights: A comparative study. (There is no publication house). Damascus University. 1995. p. 77

15. Dr. Mohammad Wahid Al-Deen Sewar. General orientations about the Jordanian civil law: A comparative study between the Jordanian civil law, Fiqh (Islamic jurisprudence) and Arab blogs. Dar Al-Thaqafeh publishing and distribution house. Amman. 1996. 130

16. Dr. Mahmoud Abed Al-Rahman Mohammad. The scope personal life right. Al-Nahda Al-Arabeya publishing and distribution house. Cairo. (Year of publication is not available). p. 231

17. Dr. Mamdouh Mohammad Khairy Al-Maslamy. The civil liability arising from violating one's right to protect his image in the light of the development of the modern communication means. Al-Nahda AlArabeya publishing and distribution house. Cairo. 2001. p. 12

18. Dr. Mustafa Ahmad Hijazi. The journalist's civil liability for violating someone's personal life. Al-Nahd AlArabeya publishing and distribution house. 2004. 132

19. Dr. Mamdouh Khalil Al-Bahar. The protection of personal life in the penal law. A comparative study. Dar Al-Thaqafeh Library. Amman 1996. p. 289

20. Dr. Nicola Fatoush \& Andre Bartran. Personal life and image rights. Sader Nasheroon Library. Beiruit. 2003.p. 279

21. Dr. Hisham Mohammad Farid. The penal protection for one's right to protect his image. Al-Alat Al-Haditha distribution and publishing house. Asyoot. (Year of publication is not available). p. 23 
Second: References written in French Language:

1. Souvanik Mullick \& Swati Narnaulia: Protecting Celebrity Rights Through Property Conceptions", National University of Juridical Sciences, Law Review, Kolkata,India, Vol. No.4, October-December,2008.

2. Pascale B. \& Amaud C: AHRC,PPP research stream-France:Id,2000.

3. Ravanas, J.: La protection des personnes contre la realization et la publication de leur image, Préface de Pierre Kayser, Paris, 1978.

4. Lindon (R): Observation sous trib.gr.inst, Paris, 11 juillet 1973.

5. Kayser Pile droit a 1,image,Mé langes Roubier,t.II,Dalloz et Sirey,1961 